\title{
Nonpatentable drugs and the cost of our ignorance
}

\author{
Frédéric Calon
}

$\mathrm{T}$ he pharmaceutical industry spends over US\$Io billion to fund some $90 \%$ of the $40000-80000$ randomized controlled clinical trials (RCTs) being conducted across the world at any given time. ${ }^{1-3}$ By its own estimation, the pharmaceutical industry in Canada spent Can $\$ 501.8$ million on clinical trials in 2004. ${ }^{4}$ In comparison, in 2003/04 the Canadian Institutes of Health Research spent Can\$3I.8 million in direct grants to RCTs. ${ }^{5}$

The RCT business is profitable for private pharmaceutical companies because the large trials they invest in are focused on patentable drugs. The patent system enables innovator firms to charge consumers prices that are above marginal cost and make a profit. ${ }^{2,6}$ In contrast, research on drugs without patent (i.e., nonpatentable or off-patent drugs) or with insufficient marketing prospects (orphan drugs) is funded by nonprofit or charitable organizations only. The numbers presented above show that for economic reasons alone, drugs for which a patent cannot be granted are not being developed, even when they respond to a public health need. Patients, pharmacists, physicians and other caregivers consequently cannot take full advantage of potentially effective treatments.

Must we remain ignorant of the potential efficacy of drugs simply because of their nonpatentability?

Omega- 3 polyunsaturated fatty acids ( $n-3$ fatty acids) for the prevention and treatment of Alzheimer's disease are a good example of this problem. These chemicals are essential for synapse function, but their concentrations in our cellular membranes depend on our dietary intake. Underconsumption of $n$ 3 fatty acids is commonplace in our modern society; indeed, in the United States the average intake of docosahexaenoic acid (DHA) is $60-80 \mathrm{mg} / \mathrm{d}$, in contrast to expert-panel recommendations of $200-300 \mathrm{mg} / \mathrm{d} .{ }^{7,8}$ Several preclinical and epidemiologic studies suggest that long-chain $n-3$ fatty acids such as DHA may be beneficial for Alzheimer's-related dementia., ${ }^{7,9-11}$ In animal models, DHA deprivation leads to aggravation of pathological signs of Alzheimer's disease, especially at the level of the synapses. ${ }^{9,10}$ In an epidemiologic study, ${ }^{11}$ patients with a diet high in DHA (a median of o.Io g/d) were at lower risk of Alzheimer's disease than those who consumed less DHA (median $0.03 \mathrm{~g} / \mathrm{d}$; relative risk $0.3,95 \%$ confidence interval o.I-0.9) after adjustments for sex, race, education, total energy intake and the presence of the $\varepsilon_{4}$ polymorphism of the apolipoprotein $\mathrm{E}$ gene, the ApoE $\varepsilon_{4}$ allele. Furthermore, various studies ${ }^{12-15}$ (though not all of them) ${ }^{16}$ have indicated that blood concentrations of DHA and other $n-3$ fatty acids are lower in patients with Alzheimer's-related dementia. Because n-3 fatty acids are readily incorporated in cellular membranes, adverse effects from high consumption are rare. ${ }^{17}$

To translate these observations into evidence-based recommendations, we need large, state-of-the-art RCTs. For pri- mary prevention trials, it is reasonable to estimate (assuming an annual probability of Alzheimer's of $3 \%$ in the placebotreated population) that sample sizes of at least 4500 patientyears per group are required to achieve sufficient statistical power $(80 \%)$ to detect a $25 \%$ relative difference in the risk of Alzheimer's disease. ${ }^{18}$ RCT costs average some $\$ 5000 / y r$ per patient; investments in the area of $\$ 50$ million are therefore required, which, because $n-3$ fatty acids are a natural product that cannot be patented, could come only from nonprofit agencies. The cost of these studies nevertheless constitutes a fraction of the money spent around the world on mildly efficient palliative drugs for treatment of Alzheimer's disease, such as cholinesterase inhibitors. Indeed, if we assume that I million patients worldwide who have Alzheimer's disease are treated with cholinesterase inhibitors at an annual cost of Can $\$$ Iooo per patient, this amounts to more than Can $\$ \mathrm{I}$ billion yearly. ${ }^{19-21}$ Pfizer's own data ${ }^{22}$ state that 717 million patient-days of Aricept were purchased in 1997-2002; assuming $\$ 3$ per patient-day, this represents more than Can \$2 billion. Meanwhile, it is quite possible that suboptimal consumption of $n-3$ fatty acids, in combination with population aging, will soon translate into increasingly more patients with dementia related to Alzheimer's disease.

\section{Studies of omega-3 fatty acids would cost a fraction} of what is spent on pallia-
tive drugs for Alzheimer's.

Can we afford to invest in clinical research for nonpatented drugs? The answer, in many cases, is yes. What we tend to forget is that everyone pays at the pharmacy for the cost of private pharmaceutical research. By entrusting drug development almost entirely to the pharmaceutical companies, we may enjoy short-term savings; but in the long term, either as citizens or as patients, we will have to pay. ${ }^{2}$

Competition between manufacturers generally causes the pharmacy prices of nonpatentable drugs to be lower than those of patented ones. ${ }^{23,24}$ Thus, many nonpatentable drugs such as $n-3$ fatty acids may turn out to be cheaper in the long term than a patentable drug of the same efficacy. Folic acid, mineral and vitamin supplements are good examples of lowcost nonpatentable drugs commonly recommended by health professionals. It is estimated, for example, that I.5 million 
Americans experience osteoporotic fractures each year, with an annual cost of nearly US\$I4 billion in health care alone (ignoring lost income and other indirect costs). ${ }^{25,26} \mathrm{~A}$ 400-UI vitamin $\mathrm{D}$ and Iooo-mg calcium supplement, which has been shown to reduce the risk of fracture by at least $15 \%,,^{27,28}$ costs less than Can $\$ 200 /$ patient/yr. ${ }^{29}$ This example, like possibly that of n-3 fatty acids in Alzheimer's disease, suggests that some (perhaps many) nonpatentable drugs can reduce pharmacy and other health care costs.

Pharmaceutical companies play a pivotal role in drug discovery; yet they develop and test only those drugs for which they can get a patent. ${ }^{30}$ Instead of relying exclusively on pharmaceutical companies to determine the effectiveness of drugs and to develop new treatments, nonprofit agencies should take up the relay for nonpatentable, off-patent and orphan drugs. As of today, such propositions seem utopian, but the problem calls for economic studies on a global scale to determine where public money for health research is better invested. Since the benefit of research-generated knowledge is not limited to a nation's borders, funding could come from international organizations as well as individual governments.

To meet the health research challenges of tomorrow, the present dynamic, in which public money is focused on basic research while private funding is concentrated on clinical research, should be carefully analyzed and revised if necessary. At present, we all should realize that ignoring the potential efficacy of nonpatentable or orphan drugs carries a social cost that clearly needs recognition.

Frédéric Calon is Assistant Professor, Molecular Endocrinology and Oncology Research Center, Laval University Medical Center (CHUL), and the Faculty of Pharmacy, Laval University, Sainte-Foy, Qué.

Competing interests: None declared.

Acknowledgement: Frédéric Calon is a recipient of a New Investigator Award (Clinician) from the Canadian Institutes of Health Research.

\section{REFERENCES}

I. CenterWatch Clinical Trials Listing Service. Thomson CenterWatch Analysis Available: www.centerwatch.com (accessed 2005 Sept 8).

2. Angell M. The truth about the drug companies. New York: Random House; 2005.

3. Moher D, Bernstein A. Registering CIHR-funded randomized controlled trials: global public good. CMAJ 2004;I7I(7):750-I.

4. Patented Medicine Prices Review Board (Canada). Annex 3, table I5. In: 2004 PMPRB annual report. Available: www.pmprb-cepmb.gc.ca/english/view.asp?x $=436$ (accessed 2006 Jan II)

5. Canadian Institutes of Health Research. Schedule I to the [auditor's report and] financial statements - grants and awards for the year ended March 3I [2004]. In: CIHR annual report 2003-2004: exceptional value for Canadians. Ottawa: CIHR; 2004. Available: www.cihr-irsc.gc.ca/e/25727.html (accessed 2006 Jan II).
6. Danzon PM, Towse A. Differential pricing for pharmaceuticals: reconciling access, R\&D and patents. Int J Health Care Finance Econ 2003;3:183-205.

7. Maclean CH, Issa AM, Newberry SJ, et al. Effects of omega-3 fatty acids on cognitive function with aging, dementia, and neurological diseases. Evidence Report/ Technology Assessment No. II4. Rockville (MD): National Library of Medicine; 2005 .

8. Simopoulos AP. n-3 fatty acids and human health: defining strategies for public policy. Lipids 2001;36(Suppl):S83-9.

9. Calon F, Lim GP, Yang F, et al. Docosahexaenoic acid protects from dendritic pathology in an Alzheimer's disease mouse model. Neuron 2004;43:633-45

Io. Lim GP, Calon F, Morihara T, et al. A diet enriched with the omega-3 fatty acid docosahexaenoic acid reduces amyloid burden in an aged Alzheimer mouse model. J Neurosci 2005;25:3032-40.

II. Morris MC, Evans DA, Bienias JL, et al. Consumption of fish and n-3 fatty acids and risk of incident Alzheimer disease. Arch Neurol 2003;60:940-6.

I2. Laurin D, Verreault R, Lindsay J, et al. Omega-3 fatty acids and risk of cognitive impairment and dementia. JAlzheimers Dis 2003;5:315-22.

I3. Tully AM, Roche HM, Doyle R, et al. Low serum cholesteryl ester-docosahexaenoic acid levels in Alzheimer's disease: a case-control study. BrJ Nutr 2003;89:483-9o.

I4. Kyle DJ, Schaefer E, Patton G, et al. Low serum docosahexaenoic acid is a significant risk factor for Alzheimer's dementia. Lipids I999;34(Suppl):S245.

I5. Heude B, Ducimetiere P, Berr C; l'Étude du Vieillissement Artériel (EVA) Study Group. Cognitive decline and fatty acid composition of erythrocyte membranes the EVA Study. Am J Clin Nutr 2003;77:803-8.

I6. Wheaton DH, Hoffman DR, Locke KG, et al. Biological safety assessment of docosahexaenoic acid supplementation in a randomized clinical trial for X-linked retinitis pigmentosa. Arch Ophthalmol 2003;121:1269-78.

17. Lenth RV. Some practical guidelines for effective sample-size determination. Am Stat 2001;55:187-93.

I8. Conquer JA, Tierney MC, Zecevic J, et al. Fatty acid analysis of blood plasma of patients with Alzheimer's disease, other types of dementia, and cognitive impairment. Lipids 2000;35:1305-I2.

I9. Courtney C, Farrell D, Gray R, et al. Long-term donepezil treatment in 565 patients with Alzheimer's disease (AD2000): randomised double-blind trial. Lancet 2004; 363:2105-I5.

20. Lanctot KL, Herrmann N, Yau KK, et al. Efficacy and safety of cholinesterase inhibitors in Alzheimer's disease: a meta-analysis [review]. CMAJ 2003;I69(6):557-64.

2I. Sambrook R, Herrmann N, Hebert R, et al. Canadian Outcomes Study in Dementia: study methods and patient characteristics. Can J Psychiatry 2004;49:417-27.

22. Pfizer Canada Inc. $5^{\text {th }}$ year milestone for first Alzheimer drug approved in Canada [press release]. Montreal: Pfizer; 2002 Aug 2I.

23. IMS Health Canada. 2004 [e.g., www.imshealthcanada.com/htmen/4_2_I_42 .htm].

24. The Henry J. Kaiser Foundation. Prescription drug trends: a chartbook update. Menlo Park (CA): The Foundation; 200I.

25. International Osteoporosis Foundation. Facts and statistics about osteoporosis and its impact. Available: www.osteofound.org (accessed 2005 Sept I3).

26. Brown JP, Josse RG. 2002 clinical practice guidelines for the diagnosis and management of osteoporosis in Canada [published errata appear in CMAJ 2003; 68 (4):400, CMAJ 2003;I68(5):544 and $C M A J$ 2003;I68(6):676]. CMAJ 2002;I67(I0 Suppl):SI-34

27. Reginster JY. The high prevalence of inadequate serum vitamin D levels and implications for bone health. Curr Med Res Opin 2005;21:579-86.

28. Larsen ER, Mosekilde L, Foldspang A. Vitamin D and calcium supplementation prevents osteoporotic fractures in elderly community dwelling residents: a pragmatic population-based 3-year intervention study. J Bone Miner Res 2004;19:370-8.

29. Régie de l'assurance maladie du Québec (RAMQ). Liste de médicaments. SainteFoy (QC): Conseil du médicament; 2005.

30. Sackett DL. Time to put the Canadian Institutes of Health Research on trial [published erratum in $C M A J$ 2000;I62(3):3I9]. CMAJ I999;I6I(II):I4I4-5.

Correspondence to: Dr. Frédéric Calon, Molecular Endocrinology and Oncology Research Center, Laval University Medical Center (CHUL), 2705 blvd. Laurier, Sainte-Foy QC GIV $4 G_{2}$; fax 4I8654-276I; frederic.calon@crchul.ulaval.ca 